\title{
Differential Diagnosis between Bartholin Cyst and Vulvar Leiomyoma: Case Report
}

\section{Diagnóstico diferencial entre cisto de Bartholin e leiomioma vulvar: relato de caso}

\author{
Kelly Alessandra da Silva Tavares ${ }^{1}$ Thomas Moscovitz ${ }^{1}$ Marcos Tcherniakovsky ${ }^{1}$ \\ Luciano de Melo Pompei ${ }^{1}$ César Eduardo Fernandes ${ }^{1}$
}

${ }^{1}$ Department of Gynecology and Obstetrics, Faculdade de Medicina do ABC, Santo André, São Paulo, Brazil

Rev Bras Ginecol Obstet 2017;39:433-435.
Address for correspondence Kelly Alessandra da Silva Tavares, MD, Rua dos Democratas, 277, apartamento 41, 04305-000, São Paulo, Brazil (e-mail: kellyalessandradasilva@yahoo.com.br).

\author{
Abstract \\ Keywords \\ - vulvar neoplasms \\ - Bartholin gland \\ - leiomyoma \\ - histology \\ - case report

\section{Resumo} \\ Palavras-Chave \\ - neoplasias vulvares \\ - glândula de Bartholin \\ - leiomioma \\ - histologia \\ - relato de caso
}

Genital leiomyomas are rare tumors that can often be misdiagnosed as Bartholin cyst. We report a case of a 32-year-old patient who had a cystic nodulation in the left labium majus that was suggestive of Bartholin cyst. A resection surgery was performed, and the definitive histopathology diagnosis was vulvar leiomyoma. The macroscopic features of cystic lesions difficult the differential diagnosis between leiomyoma and Bartholin cyst; therefore, a histopathologic examination is often recommended.

Os leiomiomas genitais são tumores raros, e frequentemente são diagnosticados como cisto de Bartholin. Relatamos o caso de uma paciente de 32 anos em que ocorreu nodulação cística no grande lábio esquerdo sugestiva de cisto de Bartholin. Uma cirurgia de ressecção foi realizada, e o diagnóstico histopatológico definitivo foi leiomioma vulvar. As características macroscópicas das lesões císticas dificultam o diagnóstico diferencial entre o leiomioma e o cisto de Bartholin, de modo que o exame histopatológico é frequentemente recomendado.

\section{Introduction}

Uterine leiomyomas are benign monoclonal tumors, and the most frequent site for their occurrence is the muscle cells of the myometrium. However, they develop in any site where smooth muscle cells are present, ${ }^{1}$ such as the vulva, the vagina, the ovaries, the urinary bladder, the urethra, the round ligaments, the uterosacral ligaments, the inguinal canal and the retroperitoneum. ${ }^{2,3}$

Genital leiomyomas are rare tumors. ${ }^{4}$ Less than 160 cases of vulvar leiomyoma have been reported in the literature, and this condition can often be misdiagnosed as Bartholin cyst. ${ }^{4-6}$
Some features that support the diagnosis of Bartholin cyst are everted labia minora and cystic consistency of the swelling. However, finding inverted labia minora and firm consistency of the swelling suggests vulvar leiomyoma. A histopathologic examination is often recommended for the final diagnosis. ${ }^{7}$

\section{Case Report}

\section{Patient Information}

A 32-year-old white woman presented to the gynecological outpatient service at our institution complaining of vaginal pain and a vulvar nodulation that had developed six months received

October 29, 2016

accepted

May 5, 2017
DOI https://doi.org/

10.1055/s-0037-1604178. ISSN $0100-7203$.
Copyright $\odot 2017$ by Thieme Revinter

Publicações Ltda, Rio de Janeiro, Brazil
License terms

(c) $(1) \$$ 
before. She stated feeling no abdominal pain and having no fever and urinary and intestinal disorders. She reported tubal ligation and prolonged menstrual bleeding.

\section{Physical Examination}

Her general physical and systemic examinations were unremarkable. Upon local examination, a $5 \times 5 \mathrm{~cm}$ cystic lesion in the lower part of left labium majus was observed. It was clinically diagnosed as Bartholin cyst.

\section{Diagnostic Assessment}

Baseline investigations were performed with a transvaginal ultrasound that evidenced multiple intramural uterine leiomyomas, with the largest measuring $28 \mathrm{~mm}$. The uterine volume was $239 \mathrm{cc}$. The vulvar region was not assessed with ultrasound because the first hypothesis was Bartholin cyst.

\section{Interventions}

Nine months after the initial consultation, the patient came back for surgery, and we observed a growth in the tumor during this period; we found a fibroelastic mass of $\sim 10 \mathrm{~cm}$. The tissue appeared to be a leiomyoma, which made us question the initial hypothesis of Bartholin cyst. A specimen was sent for a histopathologic examination.

\section{Follow-Up and Outcomes}

The patient had an uneventful postoperative recovery, and was discharged on the first postoperative day. A gross examination of the excised tumor of the left labium majus showed: a piece with irregular surface, mousey and firm tissue, measuring $8 \times 6 \times 3 \mathrm{~cm}$. Microscopy revealed a mature tumor of mesenchymal nature characterized by proliferation of spindle cells similar to smooth muscle cells. There were no indications of malignancy. The final diagnosis was leiomyoma.

The patient was called for follow-up after two weeks and was asymptomatic; one year later, no recurrence was observed.

\section{Discussion}

Uterine leiomyomas are very common benign tumors; however, their occurrence in the vulva is rare. Less than 160 cases of vulvar leiomyoma have been reported in the literature. ${ }^{4-6}$

The mean age when these tumors tend to occur varies from 13 to 71 years, and they usually occur as solitary lesions, with an average tumor size of 0.5 to $15 \mathrm{~cm}^{8}$ Corroborating with the cases described in the literature, we report a 8 -cm single vulvar lesion in a 32-year-old woman who complained of pain in the vulvar region 6 months prior to the consultation. Nevertheless, vulvar leiomyomas are usually asymptomatic, but sometimes can cause swelling and local discomfort.

Ultrasound is the most reliable and widely used diagnostic tool for uterine and extra uterine leiomyomas, and magnetic resonance imaging is sparingly used in cases that are difficult to diagnose. ${ }^{4}$ The simultaneous development of vulvar and uterine leiomyomas is very common. ${ }^{9}$ In our case report, a transvaginal ultrasound evidenced an increase in uterine volume associated with the leiomyoma.
When the patient was first evaluated, the main hypothesis was a Bartholin cyst. Most vulvar leiomyomas are usually misdiagnosed as Bartholin cyst or abscess initially. ${ }^{4-6,10,11}$ After the surgery, a specimen was sent for a histopathologic examination that confirmed the vulvar leiomyoma diagnosis. Degenerative alterations are very common; some authors have reported myxoid degeneration in some cases of vulvar leiomyoma. ${ }^{12,13}$ However, no degenerative alteration was observed in our case.

These lesions need to be surgically excised, and the prognosis is good if they are completely removed. ${ }^{14}$ Close long-term follow-up is required because of the high risk of recurrence, ${ }^{8}$ but no recurrence was observed after one year of follow-up in this patient. Excision of the tumor with some of the surrounding normal tissue is the treatment of choice. It decreases the rate of recurrence and increases the five-year survival rate. ${ }^{8}$

In conclusion, vulvar leiomyomas are very rare. The macroscopic features of cystic lesions difficult the differential diagnosis between leiomyoma and Bartholin cyst. A histopathologic examination is often recommended for the final diagnosis.

\section{Informed Consent}

Consent was taken for the procedure and publication.

\section{Conflicts of Interest}

The authors of this manuscript have no conflicts of interest to disclose.

\section{Contribution to Authorship}

KAST was responsible for the conception and design of the study, the acquisition of data, and the draft of the article; TM and MT critically revised the article for important intellectual content; LMP critically revised the article for important intellectual content, and gave the final approval for the version that was submitted; CEF gave the final approval for the version that was submitted.

\section{Note}

This research received no specific grants from any public, private or non-profit funding agencies.

\section{References}

1 Weston G, Healy DL. Uterine fibroids. In: Shaw RW, Luesley D, Monga A, editors. Gynaecology. 4th ed. Edinburgh: Elsevier Science; 2011. p. 473-85

2 Hillard P. Benign diseases of the female reproductive tract. In: Berek J, Adashi E, Hillard P, editors. Novak's gynecology. 12th ed. Baltimore: Williams \& Wilkins; 1996. p. 331-97.

3 Kunhardt Urquiza E, de la Cruz SI, Fernández Martínez RL, Hernández Zúñiga VE. Myomatosis of rare localization. Ginecol Obstet Mex 1997;65(12):541-544

4 Fasih N, Prasad Shanbhogue AK, Macdonald DB, et al. Leiomyomas beyond the uterus: unusual locations, rare manifestations. Radiographics 2008;28(07):1931-1948

5 Reyad MM, Gazvani MR, Khine MM. A rare case of primary leiomyoma of the vulva. J Obstet Gynaecol 2006;26(01):73-74

6 Zhao T, Liu X, Lu Y. Myxoid epithelial leiomyoma of the vulva: a case report and literature review. Case Rep Obstet Gynecol 2015; 2015:894830 
7 Pandey D, Shetty J, Saxena A, Srilatha PS. Leiomyoma in vulva: a diagnostic dilemma. Case Rep Obstet Gynecol 2014; 2014:386432

8 Nielsen GP, Rosenberg AE, Koerner FC, Young RH, Scully RE. Smooth-muscle tumors of the vulva. A clinicopathological study of 25 cases and review of the literature. Am J Surg Pathol 1996; 20(07):779-793

9 Zlatkov V, Doganov N, Macaveeva V. is A case of simultaneous development of leiomyomas of the labia majora and the uterine corpus. Rev Fr Gynecol Obstet 1989;84(04):351-353

10 Youssef A, Neji K, M’barki M, Ben Amara F, Malek M, Reziga H. Leiomyoma of the vulva. Tunis Med 2013;91(01):78-80
11 Francis SA, Wilcox FL, Sissons M. Bartholin's gland leiomyoma: a diagnostic and management dilemma. J Obstet Gynaecol Res 2012;38(06):941-943

12 Aguilera Martínez V, Pérez Santana ME, Avila Contreras MdeL, Mendoza E. [Vulvar leiomyoma. Report of a case]. Ginecol Obstet Mex 2011;79(06):382-385Spanish.

13 Zhou J, Ha BK, Schubeck D, Chung-Park M. Myxoid epithelioid leiomyoma of the vulva: a case report. Gynecol Oncol 2006; 103(01):342-345

14 Spies JB, Bradley LD, Guido R, Maxwell GL, Levine BA, Coyne K. Outcomes from leiomyoma therapies: comparison with normal controls. Obstet Gynecol 2010;116(03):641-652 